\title{
Effects of Aluminum, Iron and/or Low pH on Rice Seedlings Grown in Solution Culture
}

\author{
Farhana Jamaludin Alia, Jusop Shamshuddin", Che Ishak Fauziah, Mohd Hanif Ahmad Husni and Qurban Ali \\ Panhwar
}

Department of Land Management, Faculty of Agriculture, Universiti Putra Malaysia, 43400 Serdang, Selangor, Malaysia

*For correspondence: shamshud@upm.edu.my

\begin{abstract}
Water in the paddy field covered by acid sulfate soils having very low $\mathrm{pH}$ contains high amount of $\mathrm{Al}$ and $\mathrm{Fe}$ that affects rice growth. A laboratory study was conducted to qualify rice grown under the adverse conditions can withstand the stresses. Two rice varieties, MR 219 and MR 253, were grown hydroponically at various $\mathrm{pH}(3,4,5,6,7), \mathrm{Al}(0,20,40,60,80,100 \mu \mathrm{M})$ and $\mathrm{Fe}(0,20,40,60,80,100 \mu \mathrm{M})$ concentrations. After 14 days, rice root length and surface area were determined using a root scanner. Thereafter, organic acids released by the roots of rice were determined by high performance liquid chromatography. Results showed that the root length decreased with increasing $\mathrm{Al}$ and/or Fe concentration. On the contrary, the root length increased linearly as the $\mathrm{pH}$ of the solution increased. This phenomenon was probably in part related to the exudation of oxalic, citric and malic acids by the rice roots. It was observed that the amount of organic acids released was increased with increasing $\mathrm{Al}$ and/or Fe concentration in the solution culture. Hence, it is believed that these organic acids were responsible for chelating some of the $\mathrm{Al}$ and/or $\mathrm{Fe}$ in the solution, rendering them unavailable for their uptake by rice. In this way, rice plants can withstand some degree of $\mathrm{Al}^{3+}$ and/or $\mathrm{Fe}^{2+}$ toxicity. (C) 2015 Friends Science Publishers
\end{abstract}

Keywords: Acid sulfate soil; Chelation; Aluminum toxicity; Iron toxicity; Organic acid; Rice seedling Abbreviation: HPLC = High performance liquid chromatography; GML - Ground magnesium limestone; MARDI = Malaysian Agricultural Research Development Institute; SAS = Statistical analysis software; SEM = Scanning electron microscope

\section{Introduction}

Rice (Oryza sativa) is a staple food for over half of the world's population. More than one billion people depend on rice cultivation for their survival. Realizing the importance of rice and its economic role, the production of rice should be increased sufficiently because growth in rice production has been slower than the population growth. With little room for area expansion, improving the fertility of marginal soils (such as acid sulfate soils) is one of the ways to increase rice production worldwide. Acid sulfate soils occurring along the coastal plains of Peninsular Malaysia (Enio et al., 2011) can be used for rice cultivation if properly ameliorated (Shamshuddin, 2006). Under normal condition, rice growing on these soils performs poorly due $\mathrm{Al}^{3+}, \mathrm{Fe}^{2+}$ or $\mathrm{H}^{+}$stress (Shamshuddin et al., 2013, 2014). It is reported that low $\mathrm{pH}$ and high $\mathrm{Al}$ and/or Fe concentrations are the result of pyrite $\left(\mathrm{FeS}_{2}\right)$ oxidation when the soils are utilized for rice cultivation (Shamshuddin et al., 2004).

At $\mathrm{pH}<4.8$, dissolved $\mathrm{Al}^{3+}$ in the soil solution can reach the critical level of $30 \mu \mathrm{M}$, which can damage rice plants. Al toxicity is often related to phosphorus deficiency because a soil with high $\mathrm{Al}$ concentration will decrease the availability of $\mathrm{P}$ due to $\mathrm{Al}-\mathrm{Fe}$-phosphate interaction (Ward et al., 2008). That is why the most recognized symptom of Al toxicity is P-related inhibition of root growth.

In acid sulfate soils worldwide, the concentration of $\mathrm{Fe}^{2+}$ in the water of rice fields increases when they are flooded for rice cultivation (Muhrizal et al., 2006; Shamshuddin et al., 2014). Toxicity occurs if extractable Fe in the soils exceeds $300 \mathrm{mg} \mathrm{kg}^{-1}$ (Dobermann and Fairhurst, 2000). According to Silveira et al. (2007), Fe toxicity is considered as one of the most significant constraints in rice production, along with $\mathrm{Al}$ toxicity. However, without enough $\mathrm{Fe}$ in rice plants, chlorophyll cannot be sufficiently produced (Follett and Westfall, 1992). Under low $\mathrm{pH}$ condition, the availability of $\mathrm{Fe}$ is increased, causing an excessive accumulation of $\mathrm{Fe}$ in the leaves of rice. Visual symptom of Fe toxicity on rice is bronzing (Fairhurst and Witt, 2002). Besides bronzing leaf symptom, Fe toxicity can increase panicle sterility that reduces plant growth (Mathias and Asch, 2005).

According to Elisa et al. (2011), $\mathrm{Al}^{3+}$ and $\mathrm{Fe}^{2+}$ accumulate in rice root due to attraction to the negatively-charged cells wall, preventing cell division and elongation. Rice roots rapidly absorb $\mathrm{Al}^{3+}$ and $\mathrm{Fe}^{2+}$, causing a reduction in root length and inhibit root growth that result in the curtailment of nutrient uptake. The end 
result would be the reduction of rice yield (Elisa et al., 2011; Shamshuddin et al., 2014).

Organic acids released by rice roots under stress may play a major role in the $\mathrm{Al}^{3+}$ and $\mathrm{Fe}^{2+}$ tolerance mechanisms (Gerke et al., 1994; Shamshuddin et al., 2013, 2014) and the utilization of insoluble nutrients, especially $\mathrm{P}$ (Jones and Darrah, 1994). There are probably two mechanisms involved in acid metal tolerance by the roots of rice: (1) internal tolerance mechanism in the symplasm; and (2) exclusion mechanism in the apoplasm and at the plasma membrane (Kochian, 1995). For rice, the latter is the more important mechanism than that of the former.

In the exclusion mechanism, metals are prevented from entering or staying in the symplasm or coming into contact with sensitive intracellular sites. For example, Al tolerance is conferred by exclusion from root tip. Elisa et al. (2011) found that under stress condition, plant root were found to release greater amount of organic acids into the rhizosphere. These acids chelate Al outside the plasma membrane, thereby reducing its uptake. Ryan et al. (2001) suggested that exudation of organic acids could be active mechanism in response to environmental signals and stresses.

Organic acids are known as Al-chelating molecules. A study by Pineros and Kochian (2009) showed that low molecular weight organic acids secreted by plant root chelate $\mathrm{Al}$ in the soil solution, forming $\mathrm{Al}$-citrate or $\mathrm{Al}$ malate, preventing it from entering the root cells. Many tolerant plants share this general resistance mechanism. However, the organic acids so released by plant roots vary depending on plant species (Kochian et al., 2005). Miyasaka et al. (1991) found that the amount of organic acids secreted by plant root may determine its resistance to $\mathrm{Al}$ in the rhizosphere. This finding is in line with that of Ma et al. (2001) and Horst et al. (2010) who proved that plant root plays a critical role in the tolerance mechanism based on efflux of the organic acids. The most effective organic acid in the alleviating toxic $\mathrm{Al}$ and $\mathrm{Fe}$ effects was citric, followed by oxalic and tartaric acids. Malic, malonic and salicylic acids were moderate in detoxifying $\mathrm{Al}$ and $\mathrm{Fe}$ (Yang et al., 2013).

According to Malaysian Agricultural Research Development Institute (MARDI, 2010), rice variety MR 219 is a high yielding variety and therefore is widely grown in Peninsular Malaysia. Recently, a new rice variety named MR 253 has been released in Malaysia. This MR 253 rice variety, claimed to be acid tolerant by MARDI, is able to perform better than that of MR 219 in marginal soils. So far, no detailed study has been conducted to determine the actual performance of MR 253 variety on the acid sulfate soils. Hence, a study was conducted to determine the effects of $\mathrm{Al}^{3+}, \mathrm{Fe}^{2+}$ and low $\mathrm{pH}$ on root elongation and root surface area of rice varieties MR 219 and MR 253 and to explore the underlying mechanism of reducing $\mathrm{H}^{+}$stress as well as $\mathrm{Al}^{3+}$ and $\mathrm{Fe}^{2+}$ toxicity detoxification.

\section{Materials and Methods}

\section{Soils and their Locations of Sampling}

Soils and water samples were taken from a paddy field in the Integrated Agricultural Development Project (IADP), Kelantan, which is located in the northeastern part of Peninsular Malaysia. The soils for the characterization and classification purposes were taken at 5 depths: $0-15,15-30$, $30-45,45-60$, and $60-75 \mathrm{~cm}$ using an auger.

\section{Soil and Water Analyses}

Soil $\mathrm{pH}$ (in water) was determined by a $\mathrm{pH}$ meter. Exchangeable $\mathrm{Ca}, \mathrm{Mg}, \mathrm{K}$ and cation exchange capacity (CEC) and exchangeable cations were determined using ammonium acetate buffered at $\mathrm{pH} 7$ (Benton, 2001). Exchangeable $\mathrm{Al}$ was extracted by $1 \mathrm{M} \mathrm{KCl}$ (Barnhisel and Bertsch, 1982) and the $\mathrm{Al}$ in the extract was determined by inductively coupled plasma optical emission spectrometry (ICP-OES). Total $\mathrm{C}$ and $\mathrm{N}$ were determined by CNS TruMac Analyzer. Available $\mathrm{P}$ was determined by the method of Bray and Kurtz (1945) with the extracted P determined by auto analyzer (AA). Extractable $\mathrm{Fe}$ in the soils was determined by double acid method. It was extracted using $0.05 \mathrm{M} \mathrm{HCl}$ in $0.0125 \mathrm{M} \mathrm{H}_{2} \mathrm{SO}_{4}$. A $5 \mathrm{~g}$ sample of the soil was mixed with $25 \mathrm{~mL}$ of the extracting solution and shaken for 15 minutes. The solution was then filtered through Whatman filter paper number 42 before determining the $\mathrm{Fe}$ it contained by ICP-OES. The water taken from the paddy field was filtered through Whatman filter paper number 42 before determining its $\mathrm{pH}$. The concentration of $\mathrm{Al}$ and $\mathrm{Fe}$ in the water was determined by ICP-OES.

\section{Plant Material}

Rice (Oryza sativa L.) varieties MR 219 and MR 253 used for this study were taken from Department of Agriculture, Pasir Mas, Kelantan, Malaysia.

\section{Location, Materials and Experimental}

This study was carried out at the Faculty of Agriculture, Universiti Putra Malaysia, Serdang, Malaysia. It was conducted in a laboratory under hydroponic condition at the ambient temperature. Seeds of rice (varieties MR 219 and MR 253) were soaked in a hormone-based chemical (Zappa ${ }^{\mathrm{TM}}$ ) for $24 \mathrm{~h}$ and then left in the dark place for another $24 \mathrm{~h}$.

This was a short-term experiment conducted in two phases; the method used was modified from that of Elisa et al. (2011). In the first phase experiment, three pre-soaked seeds were transferred into test tubes containing $0.5 \mathrm{mM}$ $\mathrm{CaCl}_{2}$ solution at various concentrations of $\mathrm{Al}(0,20,40,60$, 80 and $100 \mu \mathrm{M})$ using $\mathrm{AlCl}_{3}, \mathrm{Fe}(0,20,40,60,80$ and 100 $\mu \mathrm{M})$ using $\mathrm{FeCl}_{3}$ and mixtures of $\mathrm{Fe}$ and $\mathrm{Al}(0,20,40,60$, 80 and $100 \mu \mathrm{M})$. In the second phase experiment, three pre- 
soaked seeds were transferred into test tubes containing water taken from the paddy field. For this experiment, the $\mathrm{pH}$ of the water was adjusted to various levels $(3,4,5,6$ and 7) using either $0.01 \mathrm{M} \mathrm{HCl}$ or $0.01 \mathrm{M} \mathrm{NaOH}$. For both phases of the study, the seeds of rice were allowed to grow in the tubes for 14 days. No fertilizers were added to promote the growth of the rice seedlings.

\section{Determination of Root Morphology}

At day 14 , root length $(\mathrm{cm})$ and root surface area $\left(\mathrm{cm}^{2}\right)$ of rice for both phases of the study were determined using a root scanner, model Win RHIZO 2012.

\section{Visual Observation of Rice Root}

Rice root was observed under scanning electron microscope (SEM). The roots of the rice seedlings were cut into pieces, pre-fixed with $4 \%$ glutaraldehyde overnight and washed with $0.1 \mathrm{M}$ sodium cacodylate buffer 3 times for 30 minutes. Osmium tetraoxide buffer $(1 \%)$ was used for post fixation. After series of dehydration in acetone $(35,50,75$, 95 and 100\%), the samples were dried in a critical point dryer and mounted on aluminum stubs, sputter-coated in gold and viewed under SEM (JEOL JSM-6400 attached with OXFORD INCA ENERGY 200 EDX).

\section{Determination of Organic Acids}

The organic acids in the culture solution for both phases of the study were determined using a high performance liquid chromatography (HPLC), Jasco Borwin software. About 20 $\mu \mathrm{L}$ of the samples from each treatment were injected into the HPLC with a UV detector set at 210 nm, using a Rezex ROA-organic acid $\mathrm{H}^{+}(8 \%)$ column $(250 \times 4.6 \mathrm{~mm})$ from Phenomenex Co.; $0.005 \mathrm{~N} \mathrm{H}_{2} \mathrm{SO}_{4}$ was the mobile phase with a flow rate of $0.17 \mathrm{~mL} \mathrm{~min}^{-1}$. Peaks for the organic acids detected were identified by comparing with the retention times obtained for pure organic acids injected as standards. From the peak areas, the quantity of organic acids in the samples were calculated and expressed in $\mu \mathrm{M}$.

\section{Determination of Sensitivity to Tolerance}

Two rice varieties were studied to differentiate their sensitivity to $\mathrm{Al}, \mathrm{Fe}$ and low $\mathrm{pH}$ stress. It was done via 2 methods: (1) using the slope of the graphs of the relative root length or root surface area against $\mathrm{Al}$ or $\mathrm{Fe}$ concentration; and (2) using the critical values for rice growth. The steepness of the slope of the graphs and critical values (based on the $90 \%$ relative root length or root surface area of rice seedlings) were used as a measure of $\mathrm{Al}$ or $\mathrm{Fe}$ tolerance.

\section{Statistical Analysis}

The experiments were laid out in Completely Randomized
Design (CRD) with four replications. The data collected from this study were analyzed by ANOVA for analysis of variances and Tukey test for mean comparison using SAS version 9.2 (SAS Institute, Inc., Cary, N.C., USA). All diagrams in this paper were drawn using Excel Program in the Microsoft.

\section{Results}

\section{Initial Chemical Properties of Soil and Water}

Table 1 shows the chemical characteristics of the acid sulfate soil under study. The $\mathrm{pH}$ of the topsoil was 3.64. Soil $\mathrm{pH}$ decreased consistently with depth, the lowest being 3.13 at the 60-75 cm depth. The exchangeable $\mathrm{K}, \mathrm{Ca}$ and $\mathrm{Mg}$ in the topsoil were below the sufficiency level for rice growth, while the exchangeable $\mathrm{Al}$ in the same horizon was very high $\left(>5 \mathrm{cmol}_{\mathrm{c}} \mathrm{kg}^{-1}\right)$. The available $\mathrm{P}$ was also low $(<5 \mathrm{mg}$ $\mathrm{kg}^{-1}$ ) in the topsoil. Table 2 shows that water $\mathrm{pH}$ was 2.98 , while the concentration of $\mathrm{Al}$ and $\mathrm{Fe}$ were 1060 and 192 $\mu \mathrm{M}$, respectively.

\section{First Phase Experiment}

Effect of Al on the root length and root surface area: The relative root length of MR 219 and MR 253 rice varieties were negatively and highly correlated with $\mathrm{Al}$ concentration and the equations representing the relationship are given by $\mathrm{Y}=103.54-0.89 \mathrm{x}\left(\mathrm{R}^{2}=0.97\right)$ and $\mathrm{Y}=107.45-1.07 \mathrm{x}\left(\mathrm{R}^{2}\right.$ $=0.94)$, respectively (Fig. 1a). The relative root surface area of rice seedlings for both varieties showed the same trend. They are negatively and highly correlated with $\mathrm{Al}$ concentration and the equations representing the relationships are given by $\mathrm{Y}=97.13-0.80 \mathrm{x}\left(\mathrm{R}^{2}=0.95\right)$ and $\mathrm{Y}=101.32-0.97 x\left(R^{2}=0.97\right)$, respectively (Fig. 2a). Fig. 2a shows that the slope of the graph for rice variety MR 253 was steeper compared to that of MR 219, while the critical Al concentration for variety MR 219 and MR 253 were 8.91 and $11.67 \mu \mathrm{M}$, respectively.

Effect of $\mathrm{Fe}$ on the root length and root surface area: The relative root length of MR 219 and MR 253 was negatively correlated with $\mathrm{Fe}$ concentration and the equations representing the relationship are given by $\mathrm{Y}=$ $106.57-0.92 x\left(R^{2}=0.98\right)$ and $\mathrm{Y}=103.84-0.60 x\left(R^{2}=\right.$ 0.98), respectively (Fig. 1b). The relative root surface area for both varieties showed similar trend. The equations representing the relationships are given by $\mathrm{Y}=$ $101.68-0.62 \times\left(R^{2}=0.93\right)$ and $\mathrm{Y}=97.01-0.80 \mathrm{x}\left(\mathrm{R}^{2}=\right.$ 0.98), respectively (Fig. 2b). The slope of the graph for MR 219 was less steep compared to that of MR 253. The critical Fe concentration for the growth of varieties MR 219 and MR 253 were 18.84 and $8.76 \mu \mathrm{M}$, respectively. On the contrary, MR 253 was more tolerant to $\mathrm{Fe}$ compared to that of MR 219 if it is based on the root length (Fig. 1b). 
Rice Seedlings Affected by Aluminum, Iron and/or Low pH Stress / Int. J. Agric. Biol., Vol. 17, No. 4, 2015

Table 1: The chemical properties of the acid sulfate soil used in the study

\begin{tabular}{llllllllllll}
\hline Depth & $\mathrm{pH}$ & $\mathrm{EC}$ & \multicolumn{3}{c}{ Exchangable cations $\left(\mathrm{cmol}_{\mathrm{ckg}}{ }^{-1}\right)$} & $\mathrm{Ext} . \mathrm{Fe}$ & ${ }^{*} \mathrm{CEC}$ & $\mathrm{T}$ & Total N & Avail. P & Total C \\
\hline$(\mathrm{cm})$ & & $\mathrm{mS} / \mathrm{cm}$ & $\mathrm{Ca}$ & $\mathrm{Mg}$ & $\mathrm{K}$ & $\mathrm{Al}$ & $\left(\mathrm{mg} \mathrm{kg}^{-1}\right)$ & $\left(\mathrm{cmol}_{\mathrm{c}} \mathrm{kg}^{-1}\right)$ & $\%$ & $\left(\mathrm{mg} \mathrm{kg}^{-1}\right)$ & $\%$ \\
\hline $0-15$ & 3.64 & 0.69 & 0.02 & 0.15 & 0.04 & 5.53 & 135.4 & 15.57 & 0.003 & 4.72 & 4.90 \\
$15-30$ & 3.51 & 0.57 & 0.05 & 0.10 & 0.02 & 6.43 & 208.5 & 11.12 & 0.004 & 4.28 & 1.05 \\
$30-45$ & 3.25 & 0.59 & 0.05 & 0.25 & 0.01 & 6.04 & 286.0 & 6.52 & 0.003 & 5.38 & 0.97 \\
$45-60$ & 3.24 & 0.59 & 0.04 & 0.26 & 0.03 & 5.82 & 483.1 & 9.58 & 0.003 & 40.46 & 1.26 \\
$60-75$ & 3.13 & 0.63 & 0.03 & 0.29 & 0.03 & 6.15 & 368.2 & 6.99 & 0.002 & 41.09 & 2.41 \\
\hline
\end{tabular}

${ }^{*} \mathrm{CEC}=$ cation exchange capacity

Table 2: The chemical properties of the water taken in paddy field at acid sulfate soil area

\begin{tabular}{|c|c|c|c|c|c|c|c|}
\hline$\overline{\mathrm{pH}}$ & EC & & Basic c & & $\mathrm{Fe}$ & $\overline{\mathrm{Al}}$ & $\mathrm{P}$ \\
\hline & $\mathrm{mS} / \mathrm{cm}$ & $\mathrm{Ca}$ & $\mathrm{Mg}$ & $\mathrm{K}$ & $(\mu \mathrm{M})$ & $(\mu \mathrm{M})$ & $\left(\mathrm{mg} \mathrm{L}^{-1}\right)$ \\
\hline 2.98 & 0.65 & 35.75 & 50.83 & 33.33 & 192 & 1060 & 29.03 \\
\hline
\end{tabular}
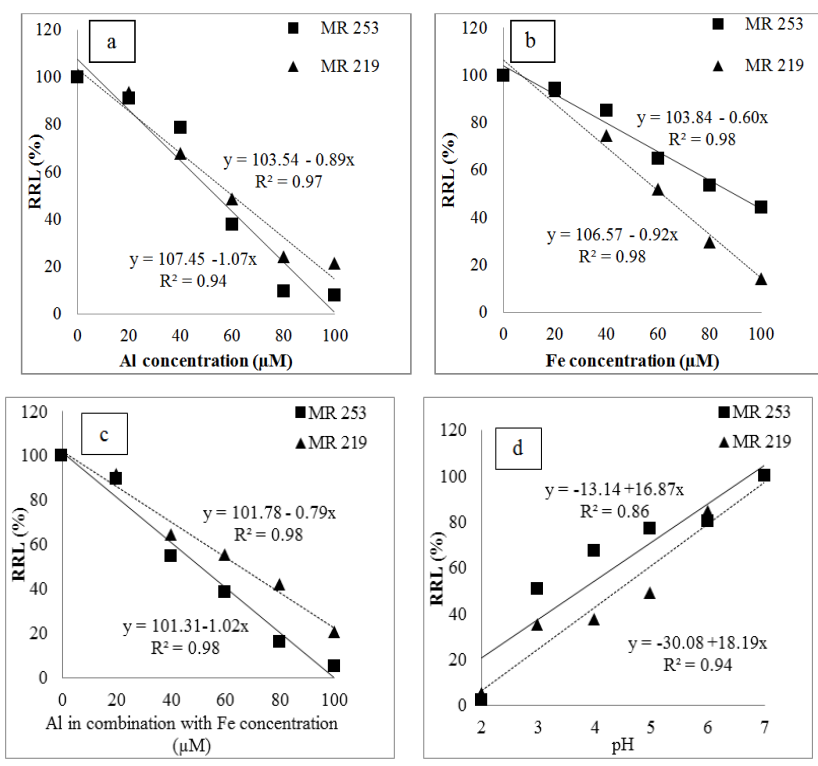

Fig. 1: Relationship between relative root length (RRL) and a) $\mathrm{Al}$ concentration, b) $\mathrm{Fe}$ concentration, c) $\mathrm{Al}$ in combination with Fe concentration and d) pHofMR 219 and MR 253

Effect of $\mathrm{Al}$ in combination with Fe on the root length and root surface area: The relative root length of MR 219 and MR 253 was negatively correlated with $\mathrm{Al}$ in combination with $\mathrm{Fe}$ and the equations representing the relationship are given by $\mathrm{Y}=101.78-0.79 \mathrm{x}\left(\mathrm{R}^{2}=0.98\right)$ and $\mathrm{Y}=101.31$ - 1.02x $\left(\mathrm{R}^{2}=0.98\right)$, respectively (Fig. 1c). The relative root surface area for both rice varieties showed the same trend. The equations representing the relationships are given by $\mathrm{Y}=99.31-0.76 \mathrm{x}\left(\mathrm{R}^{2}=0.96\right)$ and $\mathrm{Y}=97.46-$ $0.84 x\left(R^{2}=0.98\right)$, respectively (Fig. 2c). The slope of the graph for MR 219 was less steep compared to the slope of MR 253. This means that MR 253 was more sensitive to $\mathrm{Al}$ in combination with $\mathrm{Fe}$ compared to that of $\mathrm{MR}$ 219. The critical $\mathrm{Al}$ in combination with $\mathrm{Fe}$ for variety MR 219 and MR 253 were 12.25 and $8.88 \mu \mathrm{M}$, respectively.

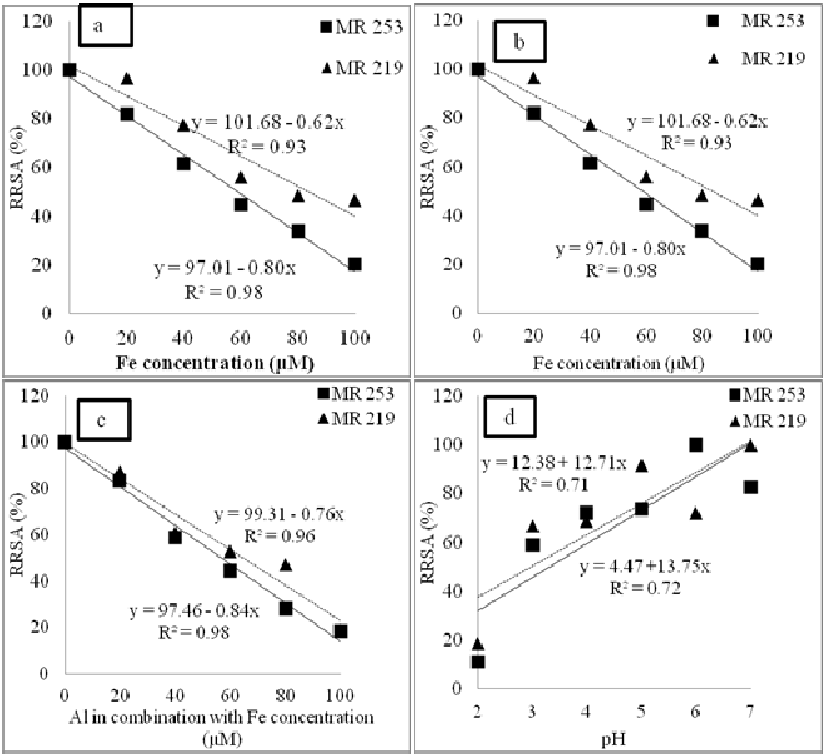

Fig. 2: Relationship between relative surface areas (RRSA) and a) $\mathrm{Al}$ concentration, b) $\mathrm{Fe}$ concentration, c) $\mathrm{Al}$ in combination with Fe concentration and d) $\mathrm{pH}$ of MR 219 and MR 253

\section{Second Phase Experiment}

The relative root length of MR 219 and MR 253 was positively correlated with $\mathrm{pH}$ and the equations representing the relationship are given by $\mathrm{Y}=-30.08$ $+18.19 \mathrm{x}\left(\mathrm{R}^{2}=0.94\right)$ and $\mathrm{Y}=-13.14+16.87 \mathrm{x}\left(\mathrm{R}^{2}=\right.$ 0.86), respectively (Fig. 1d). The relative root surface area of rice seedlings for both varieties showed similar trend. The equations representing the relationships are given by $\mathrm{Y}=12.38+12.71 \mathrm{x}\left(\mathrm{R}^{2}=0.71\right)$ and $\mathrm{Y}=4.47+$ $13.75 \times\left(R^{2}=0.72\right)$, respectively (Fig. 2d). In Fig. 2d, it is shown that the critical $\mathrm{pH}$ values for rice varieties $\mathrm{MR}$ 219 and MR 253 growth are 6.1 and 6.2, respectively. This means that MR 219 and MR 253 were more or less comparable in terms of their tolerance to low $\mathrm{pH}$ stress. 


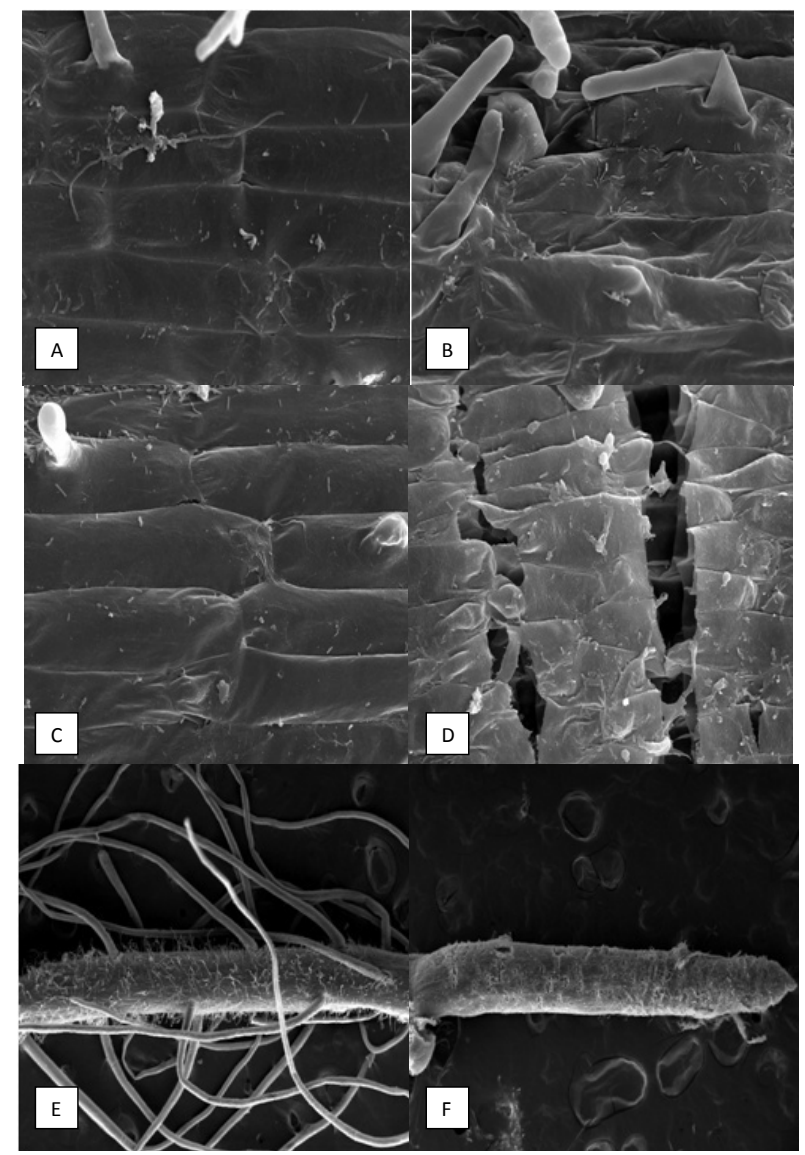

Fig. 3: Root surface of rice seedlings viewed using SEM after 14 days treatment. A) MR 219 at $0 \mu \mathrm{M}$ of $\mathrm{Fe}+\mathrm{Al}$ showing smooth surface. B) MR 219 root surface at 100 $\mu \mathrm{M}$ of $\mathrm{Fe}+\mathrm{Al}$; note shrinking surface due to $\mathrm{Al}$ and $\mathrm{Fe}$ stress. C) MR 253 at $0 \mu \mathrm{M}$ of $\mathrm{Fe}+\mathrm{Al}$ showing smooth surface. D) MR 253 root surface at $100 \mu \mathrm{M}$ of $\mathrm{Fe}+\mathrm{Al}$; note torn surface tissue $\mathrm{Al}$ and $\mathrm{Fe}$ stress. E) Root surface at $\mathrm{pH} 7$ acid sulfate soil solution showing; note root hairs developed very well. F) Root surface under low $\mathrm{pH}$

SEM observations on the cellular structures of the roots showed that both rice varieties were affected by the high concentration of $\mathrm{Al}$ in combination with Fe. Fig. 3 shows that root cellular structures of MR 219 shrank due to the presence of $\mathrm{Al}$ plus $\mathrm{Fe}$ at $100 \mu \mathrm{M}$, while those of MR 253 were ruptured. The roots of the rice seedlings were also affected by the low $\mathrm{pH}$ as shown in Fig. 3F. For rice growing under high $\mathrm{pH}$ condition, its root hairs were well developed; however, when the $\mathrm{pH}$ was reduced, the root hairs were either absent or their development was significantly curtailed.

\section{Secretion of Organic Acids by Rice Root under Al Stress}

Fig. $4 \mathrm{a}$ and $5 \mathrm{a}$ show organic acids exuded by MR 253 was higher compared to those of MR 219. Malate exuded by MR 253 was probably activated by the exposure to $\mathrm{Al}$ and
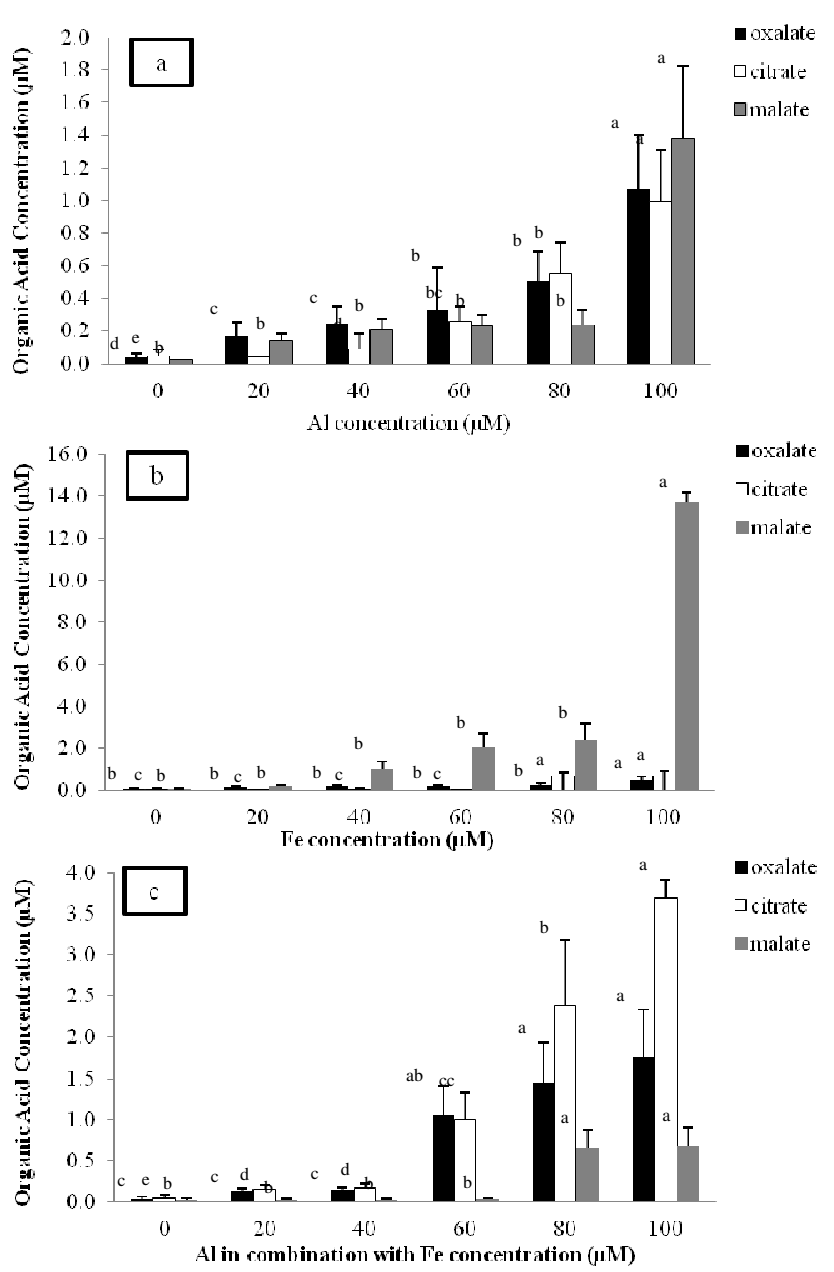

Fig. 4: Exudation of organic acids by rice root MR 219 under a) $\mathrm{Al}$ concentration b) $\mathrm{Fe}$ concentration c) $\mathrm{Al}$ in combination with $\mathrm{Fe}$ concentration

was significantly higher compared to that of MR 219 . However, there is no significant difference in citrate and oxalate exudation between both varieties at low $\mathrm{Al}$ concentration. Fig. 4a shows that the root of MR 219 secreted high amount of organic acids at high $\mathrm{Al}$ concentration. The exudation of organic acids by MR 253 showed the same trend as that of MR 219 (Fig. 5a).

\section{Organic Acids Secretion under Fe Stress}

As depicted in Fig. $4 \mathrm{~b}$ and $5 \mathrm{~b}$, both rice varieties secreted high amount of organic acids at high concentration of $\mathrm{Fe}$, with MR 253 secreted more organic acids compared to that of MR 219, especially citrate and oxalate. For MR 219, the root secreted higher amount of malate compared to that of MR 253.

\section{Organic Acids Secretion under the Stress of Al in Combination with $\mathrm{Fe}$}

It is seen in Fig. $4 c$ and $5 c$ that organic acids exuded by MR 
253 was higher than that of MR 219. Malate, citrate and oxalate exuded by MR 253 was activated by the exposure to $\mathrm{Al}$ and $\mathrm{Fe}$ and were significantly higher compared to that of MR 219. The root of MR 219 secreted more organic acids at high $\mathrm{Al}$ and $\mathrm{Fe}$ concentration compared to those at low concentration (Fig. 4c). As the $\mathrm{Al}$ and Fe increased, the exudation of organic acids was increased. The exudation of organic acids by MR 253 showed the same trend as that of MR 219 (Fig. 5c).

\section{Organic Acids Secretion under Low pH Stress}

The exudation of organic acids due to $\mathrm{H}^{+}$stress for variety MR 219 and MR 253 is depicted in Fig. 6 and Fig. 7, respectively. It was observed that the root of MR 219 secreted higher amount of organic acids at low $\mathrm{pH}$ compared to those at high $\mathrm{pH}$. As the $\mathrm{pH}$ increased, the exudation of organic acids was reduced. The trend for the exudation of organic acids by MR 253 was similar to that of MR 219 (Fig. 7).

\section{Discussion}

The soil under study was a true acid sulfate soil. It was classified as Typic Sulfaquept (Soil Survey Staff, 2010), shown by its low soil $\mathrm{pH}(<3.5)$ and the presence of yellowish jarosite within the $0-50 \mathrm{~cm}$ depth (Shamshuddin, 2006). Under this condition, the concentration of $\mathrm{Al}$ and $\mathrm{Fe}$ in the water was expected to be above the critical level for rice growth (Shamshuddin et al., 2013, 2014). The water $\mathrm{pH}$ was also expected to be below the critical level of 6 (Elisa et al. 2011).

The concentration of $\mathrm{Al}$ in water is dependent on its $\mathrm{pH}$. As the $\mathrm{pH}$ falls below 5.0, the concentration of $\mathrm{Al}$ increases. In the current study, the $\mathrm{pH}$ of the water was 3.98; hence, $\mathrm{Al}$ concentration was expected to be high, exceeding the critical level for rice growth (Shamshuddin et al., 2013, 2014). Al concentration in the water of $1060 \mu \mathrm{M}$ was far above the critical level of $15 \mu \mathrm{M}$ (Elisa et al., 2011). Data in Table 1 show that the exchangeable $\mathrm{Ca}$ and $\mathrm{Mg}$ were below the critical level. The required level of Ca is $2 \mathrm{cmol}_{\mathrm{c}} \mathrm{kg}^{-1}$ soil (Palhares, 2000), while that of $\mathrm{Mg}$ is $1 \mathrm{cmol}_{\mathrm{ckg}} \mathrm{kg}^{-1}$ soil (Dobermann and Fairhurst, 2000). Ca and Mg deficiencies can be alleviated by applying ground magnesium limestone (GML) at the appropriate rate (Shamshuddin, 2006, 2014).

Due to high Al concentration, the growth of rice root was inhibited. Many studies have been conducted to explain the causes of $\mathrm{Al}$ inhibiting the growth of crop roots. For instance, Liao et al. (2006) found that non-tolerant Al plants were badly affected by exposure to $\mathrm{Al}$. $\mathrm{Al}$ disturbs the growth of cells in the elongation zone of roots (Bian et al., 2013). Furthermore, Barker and Pilbeam (2007) explained that $\mathrm{Al}$ can reduce root cell division; hence, it causes disruption of root cap processes, inhibiting root elongation. We believed that $\mathrm{Al}$ can affect rice roots in similar fashion. Elisa et al. (2011) explained that soluble $\mathrm{Al}^{3+}$ accumulated

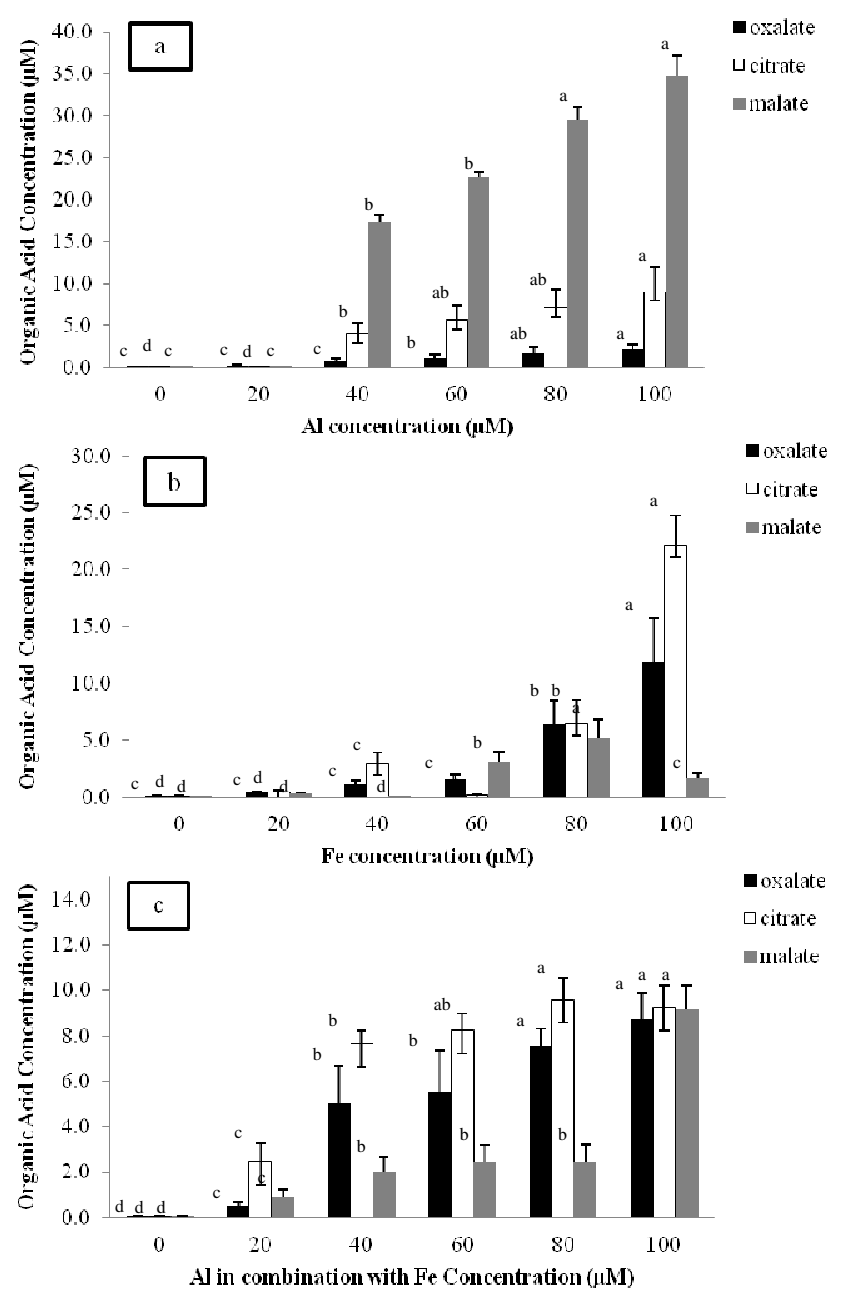

Fig. 5: Exudation of organic acids by rice root MR 253 under a) $\mathrm{Al}$ concentration b) $\mathrm{Fe}$ concentration c) $\mathrm{Al}$ in combination with $\mathrm{Fe}$ concentration

in the rice root tissue prevented cell division and eventually its elongation. It is likely that rice variety MR 253 was more tolerant to $\mathrm{Al}$ compared to that of MR 219 (based on root surface area). However, data from root length study showed otherwise. It probably means that these two rice varieties have no difference in terms of their tolerance to $\mathrm{Al}$ toxicity.

We believed that more $\mathrm{Al}^{3+}$ were accumulated in the root apex (elongation zone, root cap and meristem) compared to that of the mature root tissue. Initially, the root apex rapidly bound $\mathrm{Al}^{3+}$ in the apoplast with the rate becoming lower thereafter (Bian et al., 2013). The rapid binding of $\mathrm{Al}$ was probably due to the presence of pectic matrix in the apoplast cell walls. This pectic matrix contained carboxylic groups that were negatively-charged and have high affinity for $\mathrm{Al}^{3+}$ (Chang et al., 1999). The binding between the pectic matrix and $\mathrm{Al}$ caused loosening of enzyme in the cell walls, resulting in the loss of its function. Hence, it decreased cell wall extensibility physically and physiologically. Thus, the root length was 


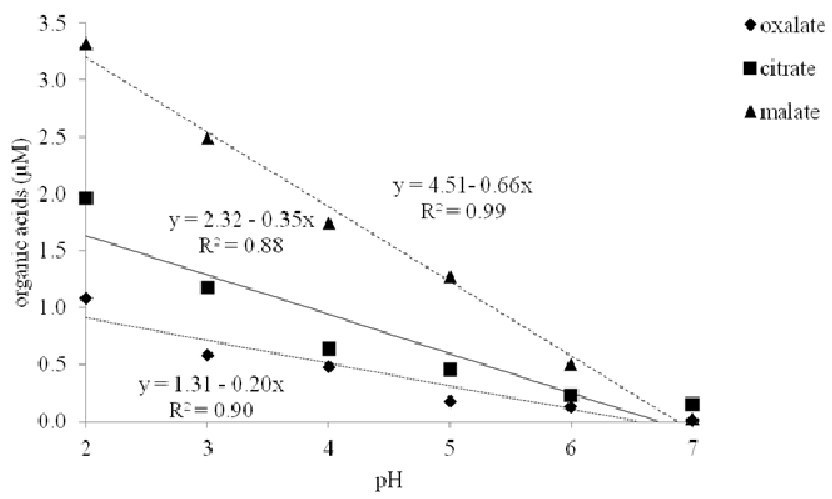

Fig. 6: Exudation of organic acids by rice root MR 219 under $\mathrm{pH}$ stress

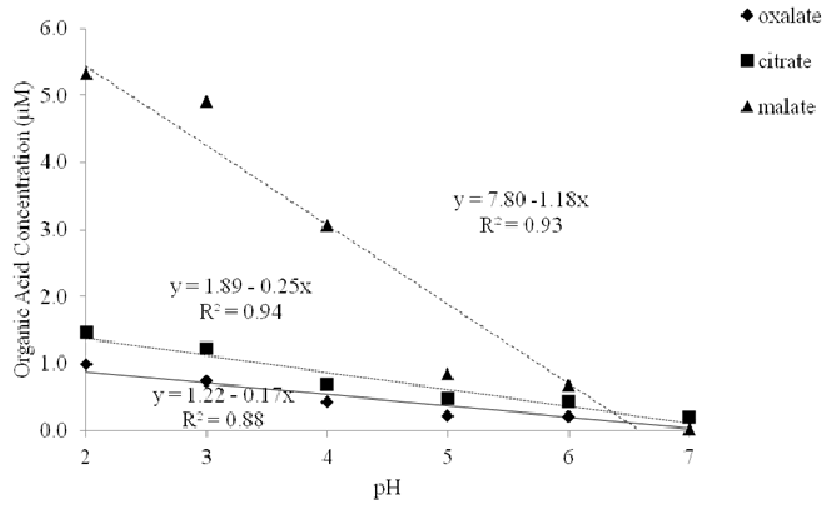

Fig. 7: Exudation of organic acids by rice root MR 253 under $\mathrm{pH}$ stress

reduced and the root growth was curtailed due to less nutrients uptake (Wehr et al., 2004).

Plasma membrane can acts as a barrier of $\mathrm{Al}$ because ions like polyvalent $\mathrm{Al}^{3+}$ are insoluble in the lipid bilayers. However, Klug et al. (2011) found that up to one half of the total of $\mathrm{Al}$ in the root apex was located in the symplasm. When $\mathrm{Al}$ crossed the membrane, many potential harmful interactions can occur. Al bound to the lipid bilayer inhibited transport, displaced ions from critical sites and disrupted intracellular metabolism (Delhaize and Ryan, 1995).

The critical level for Fe varies depending on the vegetative stage of rice growth. According to Dobermann and Fairhurst (2000), highly tolerant rice variety can withstand $\mathrm{Fe}$ of up to $300 \mathrm{mg} \mathrm{kg}{ }^{-1}$. In acid sulfate soils, extractable $\mathrm{Fe}$ varies widely depending on the environmental conditions. $\mathrm{Fe}^{2+}$ (the form of iron toxic to rice) concentration in water increases with flooding and it may exceed the critical level. For this study, the soil was taken during dry season and the extractable $\mathrm{Fe}$ in the topsoil was less than $300 \mathrm{mg} \mathrm{kg}^{-1}$, but at the lower depth it exceeded this value. Fe concentration in the water was 192 $\mu \mathrm{M}$, way above the respective critical level of 18.84 and
$8.76 \mu \mathrm{M}$ found for MR219 and MR 253. Hence, rice planted on this soil is expected to suffer from $\mathrm{Al}^{3+}$ and/or $\mathrm{Fe}^{2+}$ stress (Zhu et al., 2009; Shamshuddin et al., 2013, 2014).

Root growth was also inhibited by the excess of $\mathrm{Fe}$. The $\mathrm{pKa}$ of $\mathrm{Fe}$ is 3 , so its availability in the water was very high. This metal can be taken up by rice roots in the form of $\mathrm{Fe}^{2+}$. This form of $\mathrm{Fe}$ would be available when the paddy field was flooded for rice cultivation (Muhrizal et al., 2006). Plants have two distinct mechanisms to take Fe, Strategy I and Strategy II (Marschner, 1995). Strategy I involves acidification, reduction and transportation at the plasma membrane of the root epidermal cells, while Strategy II is secretion of phytosiderophores in response to Fe deficiency. For rice, it can adapt both mechanisms because it is growing under anaerobic conditions where soluble iron is prevalent. $\mathrm{Fe}^{2+}$ is taken up at the root cortex, which enter the xylem. When $\mathrm{Fe}^{2+}$ was abundant within the cell, it might catalyze the active oxygen generation (Marschner, 1995). The activity of phenol oxidases increased and the oxidized polyphenols later accumulated, resulting in $\mathrm{Fe}$ toxicity (Mathias and Asch, 2005).

It is claimed that MR 253 is slightly tolerant to acidity. However, our results indicated no significant difference between MR 253 and MR 219. We found that at very low $\mathrm{pH}$, the root hairs of both varieties were either absent or poorly developed, but when the $\mathrm{pH}$ was above 6 , the root hairs were in perfect order. This was because rice requires the $\mathrm{pH}$ of about 6 to grow optimally. But, water $\mathrm{pH}$ in our study area was 3.98. It means that under natural conditions, acid sulfate soils in Malaysia are unsuitable for rice cultivation.

The critical water $\mathrm{pH}$ for both rice varieties was about 6, which is similar to that obtained by Elisa et al. (2011). This $\mathrm{pH}$ level is rather unusual for the areas covered by acid sulfate soils in Malaysia (Shamshuddin, 2006). To raise water $\mathrm{pH}$ to the required level we need at least to apply $4 \mathrm{t}$ $\mathrm{GML} \mathrm{ha}^{-1}$ (Rosilawati et al., 2014). Even at this rate of lime application, water $\mathrm{pH}$ was below 5 , meaning that the rice was still subjected to $\mathrm{Al}$ toxicity (Shamshuddin et al., 2013, 2014). Liming at higher rate is uneconomical and therefore not sustainable in the long run. However, due to GML application at $4 \mathrm{t} \mathrm{ha}^{-1}$ rice is able to grow and produces reasonable yield due to its ability to protect itself against acidity (Shamshuddin et al., 2014).

The $\mathrm{pH}$ of water is dependent on $\mathrm{Al}$ and/or $\mathrm{Fe}$ concentration; the respective pKa of these metals is 5 and 3 . At $\mathrm{pH}$ below their $\mathrm{pKa}$, the metals dissolved readily to exist in their ionic forms. In the current study, the $\mathrm{pH}$ of the water taken from the paddy field was 2.98 , while the concentration of $\mathrm{Al}$ and $\mathrm{Fe}$ were 1060 and $192 \mu \mathrm{M}$, respectively. Thus, it was possible that the organic acids so exuded by the rice roots at low $\mathrm{pH}$ was not due to $\mathrm{H}^{+}$stress only, but more importantly because of the presence of high concentration of $\mathrm{Al}$ and/or Fe. This explanation is consistent with that of Pineros and Kochian (2009) who explained that less organic 
acids were secreted by the rice roots at high $\mathrm{pH}$ due to the immobilization of the phytotoxic $\mathrm{Al}^{3+}$. If the organic acids were indeed exuded due to low $\mathrm{pH}$ stress as it happens in corn, the plausible mechanism would be as follows. We know that the pKa of many organic acids ranges from 4 to 5 (De Coninck, 1978). In the case of corn, oxalic acid hydrolyzes following this equation:

$$
\mathrm{H}_{2} \mathrm{C}_{2} \mathrm{O}_{4}+\mathrm{H}_{2} \mathrm{O} \rightarrow \mathrm{HC}_{2} \mathrm{O}_{4}^{-}+\mathrm{H}_{3} \mathrm{O}^{+}, \mathrm{pKa}>4
$$

At low pH (for example 3), oxalic acid was exuded by the rice roots. If the water $\mathrm{pH}$ was below its $\mathrm{pKa}$ value, the reaction would be in the reverse order. That means at the solution-root interface, solution $\mathrm{pH}$ would approach the value of 4 . Hence, the stress on rice due to low $\mathrm{pH}$ condition was somewhat alleviated.

Citric, oxalic and malic acids were released by MR 219 and MR 253 under stress. According to Yang et al. (2013), the efficacy of organic acids in the alleviating $\mathrm{Al}$ and Fe toxicity was in the order of citric $>$ oxalic $>$ malic. This finding is consistent with the study of Bian et al. (2013) and Miyasaka et al. (1991) who found that aluminum-tolerant rice cultivar released more citrate than oxalate. The secretion of organic acids could have occurred immediately after the positively-charged $\mathrm{Al}^{3+}$ ions touched the negatively-charged membrane surfaces and pectin cell walls (Horst et al., 2010). Once this happened, the organic acids so released from the root cells bound the $\mathrm{Al}^{3+}$ to form organo-Al-complex, preventing it from accumulating in the apoplast that could damage the root cells. Hence, the $\mathrm{Al}^{3+}$ ions were deactivated and no longer toxic to the rice seedlings.

In the current study, we found that organic acids exuded by MR 253 was higher than that of MR 219, which means that MR 253 was able to reduce more Fe toxicity, making the seedlings grow better compared to that of MR 219. However, this has not been the case. We observed that the root length and root surface area of MR 219 were higher and had higher critical $\mathrm{Fe}$ value compared to that of MR 253 even though the secretion of organic acids for MR 219 showed otherwise.

In conclusion, both MR 219 and MR 253 rice varieties were affected significantly by low $\mathrm{pH}$ and high $\mathrm{Al}$ and/or $\mathrm{Fe}$ concentration, shown by the decrease in root length and root surface area with increasing $\mathrm{Al}$ and/or $\mathrm{Fe}$ concentration. At very high $\mathrm{Al}$ and/or Fe concentration, the cellular structures of the rice roots were severely damaged. The respective critical Al concentration for MR 219 and MR 253 rice varieties was 8.91 and $11.67 \mu \mathrm{M}$, while that of Fe was 18.84 and $8.76 \mu \mathrm{M}$. On the contrary, the root length increased as the $\mathrm{pH}$ of the water increased. The best $\mathrm{pH}$ for the growth of both rice varieties was about 6 . Under adverse conditions, rice has mechanisms to protect itself against $\mathrm{Al}$ and/or Fe toxicity. When the concentration of $\mathrm{Al}$ and/or Fe was high its roots secreted organic acids that chelated $\mathrm{Al}$ and $\mathrm{Fe}$, rendering them unavailable for the uptake by the rice roots.

\section{Acknowledgements}

We wish to acknowledge Universiti Putra Malaysia and the Ministry of Education, Malaysia (the research is funded by LRGS - Food Security) for financial and technical supports. Not to forget my dearest husband, Ahmad Fikri Mohd Samsudin and my family for the moral support.

\section{References}

Barker, A.V. and D.J. Pilbeam, 2007. Handbook of Plant Nutrition, $1^{\text {st }}$ edition, p: 613. CRC/Taylor and Francis, London, UK

Barnhisel, R. and P.M. Bertsch, 1982. Aluminium. In: Methods of Soil Analyses, Part 2: Chemical and Mineralogical properties, pp: 275-300. Page, A.L., R.H. Miller and D.R. Keeney (eds.). American Soc. of Agronomy and Soil Sci. Soc. of America, Madison, Wisconsin, USA

Benton, J.J., 2001. Laboratory Guide for Conducting Soil Tests and Plant Analysis, $1^{\text {st }}$ edition, CRC Press LLC, USA

Bian, M., M. Zhou, D. Sun and C. Li, 2013. Molecular approaches unravel the mechanism of acid soil tolerance in plants. Crop J., 1: 91-104

Bray, R.H. and L.T. Kurt, 1945. Determination of total, organic and available forms of phosphorus in soils. Soil Sci., 59: 39-45

Chang, Y.C., Y. Yamamoto and H. Matsumoto, 1999. Accumulation of aluminum in the cell wall pectin cultured tobacco (Nicotiana tobacum L.) cells treated with a combination of aluminum and iron. Plant Cell Environ., 22: 1009-1017

De Coninck, F., 1978. General Chemistry for Soil Scientists. International training center for postgraduate soil scientists, Ghent University, Belgium

Dobermann, A. and T. Fairhurst, 2000. Rice Nutrient Disorders \& Nutrient Management. Handbook series Potash \& Phosphate Institute (PPI), Potash \& Phosphate Institute of Canada (PPIC) and International Rice Research Institute, Canada

Delhaize, P. and R., Ryan, 1995. Aluminum toxicity and tolerance in plants. Plant Physiol., 107: 315-321

Elisa, A.A., J. Shamshuddin and C.I. Fauziah, 2011. Root elongation, root surface area and organic acid by rice seedling under $\mathrm{Al}^{3+}$ and/or $\mathrm{H}^{+}$ stress. Amer. J. Agric. Biol. Sci., 6: 324-331

Enio, K.M.S., J. Shamshuddin, C.I. Fauziah and M.H.A. Husni, 2011. Pyritization of the coastal sediments in the Kelantan plains in the Malay peninsula during the Holocene. Amer. J. Agric. Biol. Sci., 6: 393-402

Fairhurst, T.H. and C. Witt, 2002. Rice: A Practical Guide to Nutrient Management. The International Rice Research Institute, Manila, The Philippines

Follett, R.H. and D.G. Westfall, 1992. Identifying and Correcting Zinc and Iron Deficiency in Field Crops. Colorado State University cooperative extension service in action. No. 545

Gerke, J., W. Römer and A. Jungk, 1994. The excretion of citric and malic acid by proteoid roots of Lupinusalbus $L$. effects on soil solution concentrations of phosphate, iron, and aluminum in the proteoid rhizosphere in samples of an Oxisol and a Luvisol. $Z P$ flanzenernaehr Bodenk., 157: 289-294

Horst, W.J., Y. Wang and D. Eticha, 2010. The role of the root apoplast in aluminum-induced inhibition of root elongation and in aluminum resistance of plants: a review. Annal. Bot., 106: 185-197

Jones, D.L. and P.R. Darrah, 1994. Role of root derived organic acids in the mobilization of nutrients from the rhizosphere. Plant Soil, 166: 247 257

Klug, B., A. Specht and W.J. Horst, 2011. Aluminum localization in root tips of the aluminium-accumulating plant species buckwheat (Fagopyrum esculentum Moench). J. Exp. Bot., 1-10

Kochian, L.V., 1995. Cellular mechanisms of aluminum toxicity and resistance in plants. Ann. Rev. Plan. Phys. Plant Mol. Biol., 46: $237-260$ 
Kochian, L.V., M.A. Pineros and O.A. Hoekenga, 2005. The physiology, genetics and molecular biology of plant aluminum resistance and toxicity. Plant Soil, 274: 175-195

Liao, H., H. Wan, J. Shaff, X. Wang, X. Yan and L.V. Kochian, 2006. Phosphorus and Aluminum interaction in soybean in relation to $\mathrm{Al}$ tolerance. Exudation of specific organic acids from different region of the intact root system. Plant Physiol., 141: 674-684

Ma, J.F., P.R. Ryan and E. Delhaize, 2001. Aluminum tolerance in plants and the complexing role of organic acids. Trends Plant Sci., 6: 273278

MARDI, Malaysian Agricultural Research Development Institute. 2010. http://www.utusan.com.my/utusan/info.asp?y=2010\&dt=1128\&pub $=$ Utusan_Malaysia\&sec=Muka_Hadapan\&pg=mh_04.htm November 2010)

Marschner, H., 1995. Mineral Nutrition of Higher Plants, Functions of Mineral Nutrients: Micronutrients: Iron, pp: 313-323. Academic Press, London, UK

Mathias, B. and F. Asch, 2005. Iron toxicity in rice - conditions and management concepts. J. Plant Nutr. Soil Sci., 168: 558-573

Miyasaka, S.C., J.G. Buta, R.K. Howell and C.D. Foy, 1991. Mechanism of aluminum tolerance in snapbeans: Root exudation of citric acid. Plant Physiol., 96: 737-743

Muhrizal, S., J. Shamshuddin, I. Fauziah and M.H.A. Husni, 2006. Changes in an iron-poor acid sulfate soil upon submergence. Geoderma, 131: $110-122$

Palhares, M., 2000. Recommendation for fertilizer application for soils via qualitative reasoning. J. Agric. Sys., 67: 21-30

Pineros, M.A. and L.V. Kochian, 2009. Overview of the structure-function relations underlying functionality of ALMT and MATE-type transporters involved in the organic acid release $\mathrm{Al}$ tolerance response. In: Plant-Soil Interactions at low $\mathrm{pH}$ : A nutriomic approach; Proc. of the $7^{\text {th }}$ Int. Symposium on Plant-soil Interactions at Low pH, pp: 55-56. Liao, H., X. Yan, L.V. Kochian, (eds.). Guangzhou, China

Rosilawati, A.K., J. Shamshuddin and C.I. Fauziah, 2014. Effects of incubating an acid sulfate soil treated with various liming materials under submerged and moist conditions on $\mathrm{pH}, \mathrm{Al}$ and $\mathrm{Fe}$. Afr. $J$. Agric. Res., 9: 94-112
Ryan, P.R., E. Delhaize and D.L. Jones, 2001. Function and mechanism of organic anion exudation from plant roots. Anпи. Rev. Plant. Physiol. Plant Mol. Biol., 52: 527-560

Shamshuddin, J., S. Muhrizal, I. Fauziah and E.R. Van, 2004. A laboratory study of pyrite oxidation in an acid sulfate soils. Commun. Soi. Sci. Plan. Anal., 35: 117-129

Shamshuddin, J., 2006. Acid Sulfate Soils in Malaysia, $1^{\text {st }}$ edition, pp: 127. UPM Press, Serdang, Malaysia

Shamshuddin, J., A.A. Elisa, M.A.R.S. Shazana and C.I. Fauziah, 2013. Rice defense mechanisms against the presence of excess amount of $\mathrm{Al}^{3+}$ and $\mathrm{Fe}^{2+}$ in the water. Aust. J. Crop Sci., 7: 314-320

Shamshuddin, J., A.A. Elisa, M.A.R.S. Shazana, C.I. Fauziah, Q.A Panhwar and U.A. Naher, 2014. Properties and management of acid sulphate soils in Southeast Asia for sustainable cultivation of rice, oil palm and cocoa. Adv. Agron., 124: 91-142

Silveira, V.C., A.P. Oliveira, R.A. Sperotto, L.S. Espindola, L. Amara, J.F. Dias, J.B. Cunha and J.P. Fett, 2007. Influence of iron on mineral status of two rice (Oryza sativa L.) cultivars Braz. J. Plant Physiol., 19: $127-139$

Soil Survey Staff, 2010. Keys to Soil Taxonomy, $11^{\text {th }}$ edition. USDANatural Resources Conservation Service, Washington DC, USA

Ward, J.T., B. Lahner, E. Yakubova, D.E. Salt and K.G. Raghothama, 2008 The Effect of Iron on the Primary Root Elongation of Arabidopsis during Phosphate Deficiency. Plant Physiol., 147: 1181-1191

Wehr, J.B., N.W. Menzies and F.P.C. Blamey, 2004. Inhibition of cell wall autolysis and pectin degradation by cations. Plant Physiol. Biochem. 42: 485-492

Yang, L.T., Y.P. Qi, H.X. Jiang and L.S. Chen, 2013. Roles of organic acid anion secretion in aluminium tolerance of higher plants. Biomed Res. Int., 2013: 173682

Zhu, Y., T. Di, X. Chen, F. Yan and S. Schubert, 2009. Adaptation of plasma membrane $\mathrm{H}^{+}$-ATP age of rice roots to low $\mathrm{pH}$. In: Proc. of the $7^{\text {th }}$ Int. Symposium on Plant-Soil at Low pH, pp: 124-125. South China University of Technology Press, China

(Received 24 September 2014; Accepted 10 December 2014) 